\title{
Anatomical characteristics in 20-year-old Zelkova serrata trees from eight half-sib families
}

\author{
Agung Prasetyo ${ }^{1,4} \cdot$ Ryota Endo $^{2} \cdot$ Yuya Takashima $^{3} \cdot$ Futoshi Ishiguri $^{1} \cdot$ \\ Jun Tanabe ${ }^{1} \cdot$ Haruna Aiso $^{1,4} \cdot$ Fanny Hidayati $^{5} \cdot$ Jyunichi Ohshima $^{1}$. \\ Kazuya Iizuka ${ }^{1} \cdot$ Shinso Yokota $^{1}$
}

Received: 10 December 2015/Accepted: 13 July 2016/Published online: 28 July 2016

(C) The Japan Wood Research Society 2016

\begin{abstract}
Zelkova serrata (Thunb.) Makino ("keyaki" in Japanese) is an important broad-leaved species for the wood industry in Japan. To analyze the among-family variation of anatomical characteristics in Z serrata, wood fiber length (WFL), vessel element length in earlywood (VEL), fiber wall thickness (FWT), and vessel diameter in earlywood (VD) were investigated for 20-year-old trees from eight half-sib families. Mean values of WFL, VEL, FWT, and VD ranged from 1.31 to $1.51 \mathrm{~mm}, 0.19$ to $0.22 \mathrm{~mm}, 1.2$ to $2.1 \mu \mathrm{m}$, and 131 to $188 \mu \mathrm{m}$, respectively. Relatively higher $F$ values were obtained by analysis of variance for WFL and VEL, suggesting that these characteristics might be improved though the selection of mother trees under tree breeding programs. In addition, growth characteristics were not significantly correlated with anatomical characteristics, except for FWT.
\end{abstract}

Keywords Wood fiber length - Vessel element length . Fiber wall thickness $\cdot$ Vessel diameter

Futoshi Ishiguri

ishiguri@cc.utsunomiya-u.ac.jp

1 Faculty of Agriculture, Utsunomiya University, Utsunomiya, Tochigi 321-8505, Japan

2 Forest Research Institute, Chiba Prefectural Agriculture and Forestry Research Center, Sanmu, Chiba 289-1223, Japan

3 Forest Tree Breeding Center, Forestry and Forest Products Research Institute, Hitachi, Ibaraki 319-1301, Japan

4 United Graduate School of Agricultural Science, Tokyo University of Agriculture and Technology, Fuchu, Tokyo 183-8509, Japan

5 Faculty of Forestry, Gadjah Mada University, Yogyakarta 55281, Indonesia

\section{Introduction}

Zelkova serrata (Thunb.) Makino ("keyaki" in Japanese) naturally distributes in Japan, Taiwan, Korea, and China [1]. It is an important broad-leaved species for the wood industry in Japan, and the wood is used for building material, furniture, and traditional woodworking in Japan, such as fine cabinet making, carving (Buddhist sculpture), bowl turning, and decorative timber in traditional Japanese buildings, shrines, and temples [1].

Genetically superior trees in Z. serrata have been selected from the 1990s, and progeny test sites were also established [2-5]. Endo et al. [3] reported that in 4-year-old $Z$. serrata trees planted in a progeny test site at Chiba, Japan, narrow-sense heritability estimates of stem diameter and tree height were over 0.4 and 0.3 , respectively, suggesting that genetic improvement of growth characteristics is possible for $Z$. serrata. In addition, it is thought that wood quality of $Z$. serrata varies among provenances, cultivars, and individuals [6, 7]. To distinguish among the variations, $Z$. serrata trees have been treated as several cultivars, such as Aka-keyaki, Ao-keyaki (Hon-keyaki), and Ishi-keyaki [6, 7]. Isamoto [7] reported that basic density was $0.46-0.48,0.61-0.65$, and $0.53-0.57 \mathrm{~g} / \mathrm{cm}^{3}$ for Aka-keyaki, Ao-keyaki, and Zaku-keyaki cultivars, respectively. Recently, we examined stress-wave velocity of stem of eight half-sib families of 20-year-old Z. serrata trees planted with three different initial spacings [8]. Mean values of stress-wave velocity of stem ranged from 2.71 to $3.08 \mathrm{~km} / \mathrm{s}$, and significant differences were found among families [8]. Although the general information about anatomical characteristics is available for Z serrata wood [1, 9-11], information is still limited on the anatomical characteristics of selected trees from tree breeding programs of this species. 
To clarify the among-family variations, anatomical characteristics were investigated for eight half-sib families of 20-year-old Z. serrata trees.

\section{Materials and methods}

The progeny test site of Z. serrata was located in the Forestry Research Institute, Kisarazu, Chiba Prefectural Agriculture and Forestry Research Institute, Japan $\left(35^{\circ} 20^{\prime} \mathrm{N}, 140^{\circ} 02^{\prime} \mathrm{E}\right)$. Nine half-sib families originating from the prefectural forest at Kimitsu, Chiba; three types of seedlings purchased from three different places; and one clone were planted at three different initial spacings (I, $1.1 \times 1.1 \mathrm{~m}$; II, $1.3 \times 1.36 \mathrm{~m}$; III, $2.0 \times 1.8 \mathrm{~m}$ ) in 1993 $[2,3,8]$. The site had three replicate blocks for each initial spacing, and each block comprised a family row plot. Several trees naturally died before sampling. Due to an insufficient number of trees in one family, only eight halfsib families (families $\mathrm{A}-\mathrm{H}$ ) were used in this study. A total of 24 trees from the eight half-sib families grown at three different initial spacings were harvested in May 2013 (Table 1). The discs (3 $\mathrm{cm}$ in thickness) for determining anatomical characteristics were obtained from $1.2 \mathrm{~m}$ above the ground.

The following anatomical characteristics were determined: wood fiber length (WFL), vessel element length in earlywood (VEL), fiber wall thickness (FWT), and vessel diameter in early wood (VD). Because the annual ring was too narrow near the bark, wood specimens could not be obtained from several sample trees grown in three spacings. Therefore, anatomical characteristics were measured at every three annual rings from the 3rd to 12 th annual ring from pith. In addition, earlywood and latewood were defined as the pore zone and outer pore zone, respectively.
Three to five small specimens [ca. $10(\mathrm{~L}) \times 1(\mathrm{R}) \times 1$ (T) $\mathrm{mm}$ ] for determining WFL and VEL were collected from earlywood of the 3rd to 12 th annual rings. The small specimens were macerated with Schulze's solution. The macerated samples were projected on a profile projector (V-12, Nikon), and lengths of 40 fibers and 30 earlywood vessel elements were measured by a digital caliper (CD30C, Mitutoyo). For determining FWT and VD, small blocks were obtained from every third annual ring from pith. The small blocks [ca. $10(\mathrm{~L}) \times 10(\mathrm{R}) \times 10(\mathrm{~T}) \mathrm{mm}$ ] were softened with $25 \%(\mathrm{v} / \mathrm{v})$ glycerin for 8-10 h. After softening, transverse sections (15 $\mu \mathrm{m}$ in thickness) were obtained from each small block by a sliding microtome (REM 710, Yamato Koki). The sections were stained with $1 \%$ safranin for $30 \mathrm{~min}$ and then dehydrated by graded ethanol series. Dehydrated sections were dipped into xylene and mounted with Biolite (Okenshoji). Photomicrographs for each section were taken by a microscope (BX51, Olympus) equipped with a digital camera (E-P3, Olympus). FWT and VD were measured by image analysis software (ImageJ, National Institutes of Health). The double wall thickness of 50 wood fibers was measured, and FWT was defined as one half of the double wall thickness. Vessel diameter in earlywood was measured for 30 vessels in both radial and tangential directions. VD was then calculated by averaging the radial and tangential diameters of the vessels.

Analysis of variance was performed with software $(\mathrm{R}$ Core Team [12]) to analyze the differences among the eight half-sib families for all examined characteristics within radial positions and among the three initial spacings. Because an $F$ value obtained by analysis of variance test is a ratio of variance within families (or spacings) to variance between families (or spacings), it can be used for evaluating the degree of contribution of a genetic effect [13].

Table 1 Stem diameter and tree height of sample trees

\begin{tabular}{|c|c|c|c|c|c|c|}
\hline \multirow[t]{2}{*}{ Family } & \multicolumn{2}{|c|}{ Spacing $\mathrm{I}(1.1 \times 1.1 \mathrm{~m})$} & \multicolumn{2}{|c|}{ Spacing II $(1.3 \times 1.36 \mathrm{~m})$} & \multicolumn{2}{|c|}{ Spacing III $(2.0 \times 1.8 \mathrm{~m})$} \\
\hline & Stem diameter $(\mathrm{cm})$ & Tree height (m) & Stem diameter $(\mathrm{cm})$ & Tree height $(\mathrm{m})$ & Stem diameter $(\mathrm{cm})$ & Tree height $(\mathrm{m})$ \\
\hline A & 4.7 & 5.2 & 8.2 & 16.3 & 5.8 & 8.0 \\
\hline B & 5.8 & 8.1 & 6.8 & 9.9 & 9.7 & 10.9 \\
\hline $\mathrm{C}$ & 9.6 & 9.7 & 7.1 & 9.2 & 8.2 & 10.0 \\
\hline $\mathrm{D}$ & 4.8 & 5.9 & 6.1 & 8.7 & 6.6 & 8.1 \\
\hline $\mathrm{E}$ & 8.6 & 9.2 & 9.3 & 10.6 & 10.5 & 12.0 \\
\hline $\mathrm{F}$ & 6.7 & 7.9 & 6.8 & 9.2 & 9.2 & 8.6 \\
\hline G & 7.5 & 5.2 & 7.7 & 8.1 & 8.2 & 9.4 \\
\hline $\mathrm{H}$ & 7.3 & 9.1 & 8.0 & 10.7 & 6.2 & 7.7 \\
\hline Mean & 6.8 & 7.5 & 7.5 & 10.3 & 8.0 & 9.3 \\
\hline SD & 1.7 & 1.8 & 1.0 & 2.5 & 1.7 & 1.5 \\
\hline
\end{tabular}

Stem diameter was measured at $1.2 \mathrm{~m}$ above the ground

$S D$ standard deviation 


\section{Results and discussion}

\section{Radial variation of anatomical characteristics in $Z$. serrata}

Radial variations of anatomical characteristics are shown in Fig. 1. WFL increased from the 3rd to 12th annual ring. In contrast, VEL showed only small radial changes and was almost constant from pith to bark. FWT was also almost constant from the 3rd to 15 th annual ring, while VD tended to increase across the annual rings. In 148 and 210 years old Z. serrata trees, Furukawa et al. [9] reported that VEL showed almost constant from pith to bark, but WFL increased during the first 60 years from the pith and then it leveled off. Fujiwara [10] also pointed out that, in Z. serrata trees with different growth rate, WFL increased rapidly during the first 10 years or $2 \mathrm{~cm}$ from pith regardless growth rate, and FWT showed no distinct pattern or tendency to increase slightly from pith to 10 years. The results obtained in this study are almost similar to the results obtained at early stage of tree growth in previous study [9-11].

\section{Among-family variation of anatomical characteristics in $Z$. serrata}

Mean values of anatomical characteristics in each family ranged as follows: WFL, 1.31-1.51 mm; VEL, 0.19-0.22 mm; FWT, 1.2-2.1 $\mu \mathrm{m}$; VD, $131-188 \mu \mathrm{m}$ (Table 2). The cell length and cell morphology of Z. serrata have been reported by several researchers $[9,11,14]$. Furukawa et al. [9] reported that mean values of WFL from pith to the 60th annual ring ranged from 0.8-1.0 to $1.6-2.0 \mathrm{~mm}$. They also reported that VEL ranged from 0.17 to $0.20 \mathrm{~mm}$ in $Z$. serrata naturally grown trees [9]. Fujiwara [10] reported that FWT in Z. serrata from naturally and plantation-grown trees reached a maximum of more than $2.0 \mu \mathrm{m}$ at the 20th ring from pith. In addition, Tsuchiya and Furukawa [11] reported that, at the $1 \mathrm{~m}$ above the ground, VD within 20th annual ring from pith ranged from about 50 to about $150 \mu \mathrm{m}$. According to these results obtained at early stage of tree growth, WFL and VEL, and FWT in Z. serrata from eight half-sib families in this study showed almost similar values to those in $Z$. serrata reported by other researchers [9, 10, 14].

It has been reported that significant differences among families were found in anatomical characteristics in broadleaved species $[15,16]$. For example, significant differences in WFL, VEL, and VD have been reported in Robinia pseudoacacia for three individual plantationgrown trees aged 35-37 years [15]. In this study, as shown in Table 2, relatively higher $F$ values were obtained for
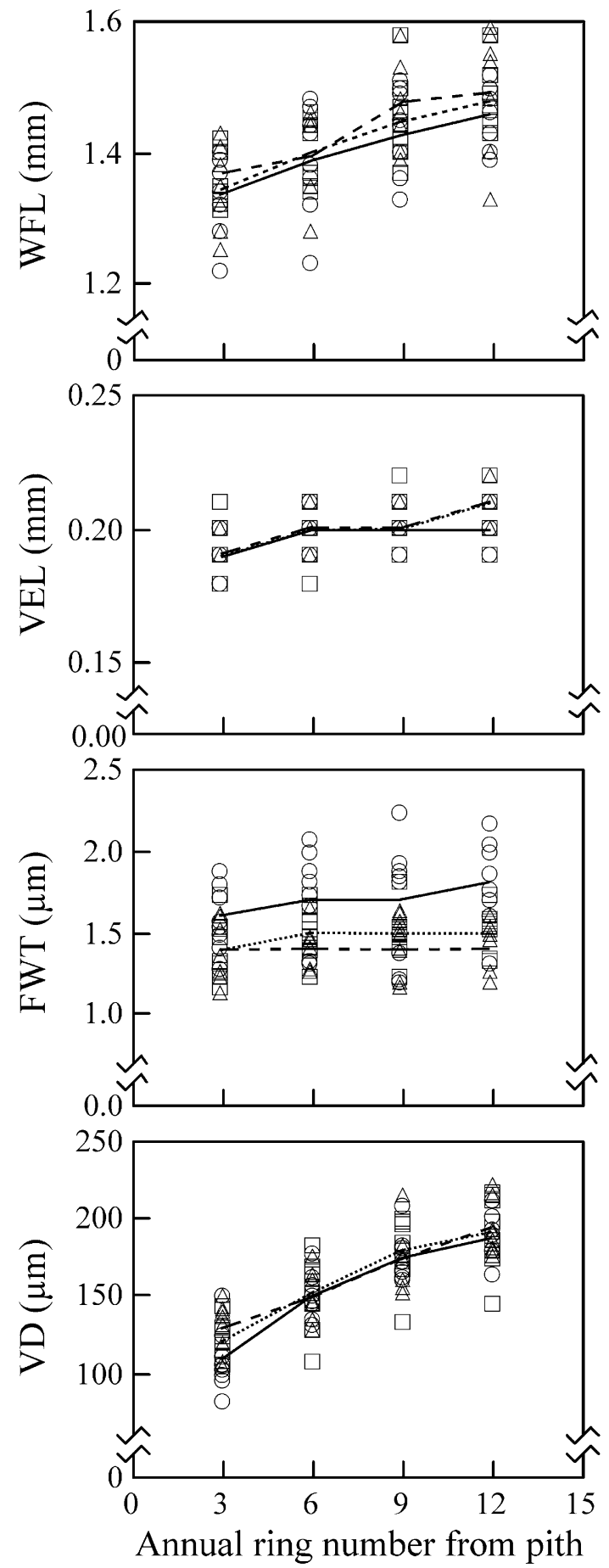

Fig. 1 Radial variation of anatomical characteristics for eight halfsib families of Z. serrata. Solid, long-dash, and short-dash lines indicate the mean values of initial spacing I $(1.1 \times 1.1 \mathrm{~m})$, II $(1.3 \times 1.36 \mathrm{~m})$, and III $(2.0 \times 1.8 \mathrm{~m})$, respectively. Open circles initial spacing I, open triangles initial spacing II, open squares initial spacing III

WFL and VEL. The higher $F$ value in some characteristics indicates that degree of genetic effects might be high in the characteristics. Therefore, WFL and VEL might be mainly 
Table 2 Mean values of anatomical characteristics for each spacing and results of analysis of variance

\begin{tabular}{|c|c|c|c|c|c|c|c|c|c|c|}
\hline \multirow[t]{2}{*}{ Character } & \multirow[t]{2}{*}{ Spacing } & \multicolumn{8}{|l|}{ Family } & \multirow[t]{2}{*}{$F$ value $(p)$} \\
\hline & & A & B & $\mathrm{C}$ & $\mathrm{D}$ & $\mathrm{E}$ & $\mathrm{F}$ & G & $\mathrm{H}$ & \\
\hline \multirow{3}{*}{$\begin{array}{l}\text { WFL } \\
(\mathrm{mm})\end{array}$} & I & $1.45(0.05)$ & $1.45(0.06)$ & $1.43(0.08)$ & $1.46(0.06)$ & $1.35(0.06)$ & $1.35(0.04)$ & $1.45(0.04)$ & $1.31(0.10)$ & $3.574(0.01)$ \\
\hline & II & $1.49(0.08)$ & $1.46(0.07)$ & $1.33(0.06)$ & $1.37(0.07)$ & $1.38(0.08)$ & $1.43(0.07)$ & $1.51(0.08)$ & $1.45(0.09)$ & $2.803(0.03)$ \\
\hline & III & $1.38(0.06)$ & $1.44(0.08)$ & $1.50(0.09)$ & $1.36(0.05)$ & $1.42(0.05)$ & $1.42(0.06)$ & $1.41(0.06)$ & $1.43(0.06)$ & $1.767(0.14)$ \\
\hline \multirow{3}{*}{$\begin{array}{l}\text { VEL } \\
\text { (mm) }\end{array}$} & I & $0.20(0.00)$ & $0.21(0.01)$ & $0.20(0.01)$ & $0.20(0.01)$ & $0.19(0.00)$ & $0.19(0.01)$ & $0.20(0.00)$ & $0.19(0.00)$ & $2.143(0.08)$ \\
\hline & II & $0.21(0.00)$ & $0.20(0.01)$ & $0.20(0.01)$ & $0.19(0.01)$ & $0.20(0.01)$ & $0.21(0.01)$ & $0.20(0.01)$ & $0.20(0.01)$ & $2.321(0.06)$ \\
\hline & III & $0.22(0.01)$ & $0.19(0.01)$ & $0.20(0.00)$ & $0.20(0.01)$ & $0.20(0.00)$ & $0.19(0.00)$ & $0.20(0.01)$ & $0.20(0.01)$ & $6.449(0.00)$ \\
\hline \multirow{3}{*}{$\begin{array}{l}\text { FWT } \\
(\mu \mathrm{m})\end{array}$} & I & $1.8(0.2)$ & $1.8(0.3)$ & $1.3(0.0)$ & $2.1(0.2)$ & $1.4(0.2)$ & $1.8(0.1)$ & $1.6(0.2)$ & $1.8(0.2)$ & $7.784(0.00)$ \\
\hline & II & $1.2(0.1)$ & $1.5(0.1)$ & $1.4(0.1)$ & $1.4(0.1)$ & $1.4(0.2)$ & $1.5(0.1)$ & $1.4(0.2)$ & $1.4(0.2)$ & $1.650(0.17)$ \\
\hline & III & $1.4(0.1)$ & $1.4(0.2)$ & $1.4(0.1)$ & $1.4(0.2)$ & $1.4(0.1)$ & $1.4(0.2)$ & $1.6(0.1)$ & $1.7(0.0)$ & $3.185(0.02)$ \\
\hline \multirow[t]{3}{*}{$\mathrm{VD}(\mu \mathrm{m})$} & I & $147(31)$ & $152(20)$ & $151(42)$ & 158 (44) & $153(46)$ & $181(25)$ & $153(38)$ & 145 (44) & $0.349(0.92)$ \\
\hline & II & $148(36)$ & $166(18)$ & $152(33)$ & 147 (30) & $156(27)$ & 163 (18) & 188 (37) & 167 (36) & $0.797(0.60)$ \\
\hline & III & $176(44)$ & $166(26)$ & 178 (31) & 153 (33) & 175 (43) & $131(10)$ & $146(46)$ & $156(22)$ & $0.978(0.47)$ \\
\hline
\end{tabular}

The mean values of a tree were calculated by averaging the values obtained at every three annual ring from 3rd to 12th annual rings from pith. The values in parenthesis followed by mean values are standard deviations. Spacing I, II, and III indicate initial spacing of $1.1 \times 1.1 \mathrm{~m}$, $1.3 \times 1.36 \mathrm{~m}$, and $2.0 \times 1.8 \mathrm{~m}$, respectively

$W F L$ wood fiber length, VEL vessel element length, $F W T$ fiber wall thickness, $V D$ vessel diameter

Table 3 Relationships between growth characteristics and anatomical characteristics

\begin{tabular}{llcc}
\hline Growth character & Anatomical character & Correlation coefficient $(n=24)$ \\
\hline Stem diameter & WFL & 0.042 & NS \\
& VEL & -0.290 & NS \\
& FWT & -0.655 & $* *$ \\
Tree height & VD & 0.036 & NS \\
& WFL & 0.122 & NS \\
& VEL & 0.145 & NS \\
& FWT & -0.635 & $* *$ \\
& VD & 0.055 & NS \\
\hline
\end{tabular}

$\overline{n \text { number of trees, WFL wood fiber length, } V E L \text { vessel element length, } F W T \text { fiber wall thickness, } V D \text { vessel }}$ diameter

** significance at $1 \%$ level, $N S$ no significance $(p>0.05)$ controlled by genetic factors. On the other hand, as shown in Table 2, the $F$ value for VD was relatively low. In VD, no significant difference in VD was found in three individual trees of 80-year old Quercus garryana [17], among clones of Dalbergia sissoo [18], and half-sib progenies of Populus deltoides [16]. These results suggest that VD is not only controlled by genetic factors but also environmental factors.

Based on the results, it is suggested that cell length in $Z$. serrata might be mainly controlled by genetic rather than environmental factors. Therefore, it is considered that wood quality related to anatomical characteristics of this species can be improved by selection of mother trees under tree breeding programs.

\section{Relationships between growth characteristics and anatomical characteristics in $Z$. serrata}

Table 3 shows relationships between growth characteristics of trees (stem diameter and tree height) and anatomical characteristics. Growth characteristics were not significantly related to all anatomical characteristics tested here $(p>0.05)$, except for FWT, suggesting that anatomical characteristics, except for FWT are independent from growth characteristics. On the other hand, Fujiwara [10] reported that relationship between FWT and radial growth rate was unclear during increasing the FWT. Therefore, further research is needed for clarifying the relationship between growth characteristics and FWT in Z. serrata. 


\section{Conclusion}

In this study, anatomical characteristics were investigated for 20-year-old Z. serrata trees from eight half-sib families. The obtained results are as follows:

1. Mean values of WFL, VEL, FWT, and VD ranged from 1.31 to $1.51 \mathrm{~mm}, 0.19$ to $0.22 \mathrm{~mm}, 1.2$ to $2.1 \mu \mathrm{m}$, and 131 to $188 \mu \mathrm{m}$, respectively.

2. In WFL and VEL, relatively higher $F$ values were obtained by analysis of variance, suggesting that these anatomical characteristics might be improved by tree breeding programs.

3. There were no significant relationships between growth characteristics and anatomical characteristics, except for FWT.

\section{References}

1. Mertz M (2011) Wood and traditional woodworking in Japan. Kaiseisha Press, Otsu

2. Kodaira T (1993) Studies on natural forests: Establishment of density control experimental site of Zelkova serrata (in Japanese). Ann Rep Chiba Pref Exp Sta 27:11

3. Endo R, Kodaira T, Akasi T (1998) Characters of excellent family of Zelkova serrata (Thunb.) Makino in Chiba Prefecture: Narrow-sense heritability of age-4 (in Japanese). Bull Chiba Pref Forest Exp Sta 9:1-4

4. Yoshino Y, Maeda M, Taniguchi S (2006) Progeny test trial of open-pollinated Zelkova serrata families: Growth of trees 12 years after planting (in Japanese). Bull Hyogo Pref Technol Cen for Agri For Fis For Sec 53:52-55

5. Kidoguchi S, Yomogida H, Kamiyama H (2010) Selection of keyaki (Zelkova serrata) plus trees and establishment of exhibition forest (in Japanese). Bull Iwate Pref For Technol Cen 18:1-6

6. Hashizume H, Furukawa I, Sakuno T, Omori H (1987) On the utilizing volume and wood quality of Zelkova serrata Makino (in Japanese with English summary). Hardwood Res 4:49-59
7. Isamoto N (2000) Anatomical characteristics on wood quality of the three strains of keyaki (Zelkova serrata) (in Japanese with English summary). J Jpn For Soc 82:87-90

8. Prasetyo A, Endo R, Takashima Y, Aiso H, Hidayati F, Tanabe J, Ishiguri F, lizuka K, Yokota S (2015) Variations in growth characteristics and stress-wave velocities of Zelkova serrata trees from eight half-sib families planted in three different initial spacings. J For Env Sci 31:235-240

9. Furukawa I, Fukutani S, Kishimoto J (1989) Characteristics of the variation of wood quality within keyaki (Zelkova serrata Makino) trees: Horizontal variations of ring width, fiber length, vessel element length, specific gravity and longitudinal compression strength (in Japanese with English summary). Hardwood Res 5:197-206

10. Fujiwara S (1998) Growth and wood properties of keyaki (Zelkova serrata Makino) (I) Variation in fiber length, fiber wall thickness and earlywood vessel lumen area from pith to bark (in Japanese with English summary). Jpn J For Plan 31:7-14

11. Tsuchiya R, Furukawa I (2010) Synchronized maturation of vessel diameter and ray width in Zelkova serrata. IAWA J 31:269-282

12. R Core Team (2015) R: a language and environment for statistical computing. R Foundation for Statistical Computing, Vienna, Austria. http://www.R-project.org/. Accessed July 21, 2015

13. Conner JF, Hartl DL (2004) A primer of ecological genetics. Sinauer Associates, Massaehusetts

14. Fujiwara S, Sameshima K, Kuroda K, Takamura N (1991) Anatomy and properties of Japanese hardwoods I. Variation of fibre dimensions and tissue proportions and their relation to basic density. IAWA Bull ns 12:419-424

15. Adamopoulos S, Voulgaridis E (2002) Within-tree variation in growth rate and cell dimensions in the wood of black locust (Robinia pseudoacacia). IAWA J 23:191-199

16. Pande PK, Dhiman RC (2012) Variations in wood anatomical properties and specific gravity of half-sib progenies of Populus deltoides. J For Res 23:491-496

17. Lei H, Milota MR, Gartner BL (1996) Between- and within-tree variation in the anatomy and specific gravity of wood in Oregon white oak (Quercus garryana Dougl.). IAWA J 17:445-461

18. Pande PK, Singh M (2005) Inter-clonal, intra-clonal, and single tree variations of wood anatomical properties and specific gravity of clonal ramets of Dalbergia sissoo Roxb. Wood Sci Technol 39:351-366 